\title{
Pemilihan Alat Kontrasepsi Non-Hormonal (Iud) di Puskesmas Kenali, Lampung Barat Tahun 2020
}

\section{The Selection of Contraception Tools Non-Hormonal Intra Uterin Device (Iud) In Kenali Primary Health Center, West Lampung in 2020}

\section{Fitri Ekasari ${ }^{1}$, Nurul Aryastuti $^{1}$, Romaita $^{1}$}

${ }^{1}$ Fakultas Kesehatan Masyarakat Universitas Malahayati, Bandar Lampung, Indonesia

Korespondensi penulis: fitri@malahayati.ac.id

Penyerahan: 23-11-2020, Perbaikan: 03-12-2020, Diterima: 25-02-2021

\begin{abstract}
The family planning program is used to suppress the high rate of population growth such as the IUD KB. Recognize Puskesmas targets in 2018 the use of family planning coverage is $80 \%$, the target achieved is $68.5 \%$. From the results of the pre-survey, it is known that 7 people (70\%) stated that if they are afraid to use the IUD, such as how to insert it, the issue of use constraints, and a sense of comfort during sexual intercourse. Puskesmas Know West Lampung Regency in 2020. Cross-sectional design quantitative research. The population of all active family planning participants in the working area of the UPT Puskesmas Kenali, West Lampung Regency. The study was conducted in June-July 2020. Data was collected using a questionnaire. Data analysis was univariate, bivariate and multivariate. There is a relationship between the level of knowledge, attitudes, economic status, husband's support, individual assessment in the Work Area of the Kenali Community Health Center in West Lampung Regency in 2020 , there is no relationship between the availability of contraceptives, the role of health workers, clinical assessment with the selection of tools in the Work Area of the Kenali Community Health Center, West Lampung Regency 2020. The most dominant relationship in the choice of contraceptives among women of childbearing age in the Work Area of the Kenali Health Center, West Lampung Regency in 2020 is the support of the husband ( $p$-value: 0,000 OR 8,635). Suggestions Opening classes for female women, such as: contraceptive counseling, contraceptive use counseling and direct contraceptive services, which are carried out regularly every month.
\end{abstract}

Keywords: Kb Non hormonal, knowledge, attitudes, economy, husband's support, individual assessment

\begin{abstract}
ABSTRAK
Program KB digunakan menekan tingginya laju pertumbuhan penduduk seperti KB IUD. Target Puskesmas Kenali tahun 2018 cakupan penggunaan KB sebesar $80 \%$, target yang tercapai sebesar 68,5\%. Dari hsail prasurvey diketahui 7 orang (70\%) diantaranya menyatakan jika takut menggunakan IUD, seperti cara pemasangan, isu kendala penggunaan, dan rasa nyaman saat berhubungan seksual, tujuan penelitian diketahui faktor yang mempengaruhi pemilihan alat kontrasepsi non hormonal (IUD) di wilayah kerja UPT Puskesmas Kenali
\end{abstract}


Kabupaten Lampung Barat tahun 2020. Penelitian kuantitatif desain CrossSectional. Populasi seluruh peserta KB aktif di wilayah kerja UPT Puskesmas Kenali Kabupaten Lampung Barat. Penelitian telah dilaksanakan bulan Juni-Juli 2020. Pengambilan data dengan kuesioner. Analisis data secara univariat, bivariat dan multivariat. Ada hubungan tingkat pengetahuan, sikap, status ekonomi, dukungan suami, penilaian individu di Wilayah Kerja Puskesmas Kenali Kabupaten Lampung Barat tahun 2020, Tidak ada hubungan ketersediaan alat kontrasepsi, peran petugas kesehatan, penilaian klinik dengan pemilihan alat di Wilayah Kerja Puskesmas Kenali Kabupaten Lampung Barat tahun 2020. Hubungan yang paling dominan pada pemilihan alat kontrasepsi pada wanita usia subur di Wilayah Kerja Puskesmas Kenali Kabupaten Lampung Barat tahun 2020 adalah dukungan suami dengan ( $p$-value 0,000 OR 8,635). Saran membuka kelas bagi WUS, seperti kegiatan penyuluhan kontrasepsi, konseling penggunaan kontrasepsi dan pelayanan kontrasepsi langsung, yang dilakukan rutin setiap bulan.

Kata kunci: Kb Non hormonal, pengetahuan, sikap, ekonomi, dukungan suami, penilaian individu

\section{PENDAHULUAN}

Kontrasepsi

nonhormonal seperti intrauterine device IUD yang digunakan oleh pemakai lebih efektif menekan tingkat kegagalan dibandingkan alat kontrasepsi hormonal seperti pil, suntik, susuk. Alat kontrasepsi nonhormonal memiliki efek samping yang lebih rendah dan harga lebih terjangkau serta jangka panjang. Problem KB hormonal biasanya berkaitan dengan fisik seperti kegemukan, bercak hitam pada kulit, menstruasi yang tidak teratur. Sementara itu kontrasepsi nonhormonal dapat meminimalkan efek samping tersebut dan hanya bersifat menghambat pembuahan (Mulyani, N. S., \& Rinawati, 2013).

Peserta program KB secara nasional tahun 2019 mencapai $62,5 \%$ atau sebanyak 38.680 .214 jiwa. Cakupan peserta KB aktif di Provinsi Lampung pada tahun 2019 sebesar $58,7 \%$. Jenis kontrasepsi yang digunakan para peserta KB aktif jenis kontrasepsi IUD sebesar $(5,1 \%)$, Metode operasi pria MOP/ MOW sebesar $(0,1 \%)$, dan implant sebesar $(0,7 \%)$, suntik sebesar $(21,4 \%)$, pil sebesar $(54,3 \%)$, dan kondom sebesar (5,0\%) (Dinkes Provinsi Lampung, 2020). Cakupan peserta KB IUD di Provinsi Lampung terlihat Fluktuatif dimana pada tahun 2015 yaitu $6,5 \%$, pada tahun 2016 sebanyak 6,2\%, pada tahun 2017 sebanyak 3,8\%, pada tahun 2018 sebanyak 5,2\%, pada tahun 2019 sebanyak 5,1\% (Dinkes Provinsi Lampung, 2020). Data Kabupaten di Provinsi Lampung pada tahun 2019, penggunaan KB IUD di Kota Bandar Lampung penggunaan KB IUD tertinggi sebanyak 16.699 peserta, Kabupaten terendah penggunaan KB IUD yakni Kabupaten Mesuji sebanyak 541 peserta, Kabupaten Tulang Bawang Barat sebanayk 665 peserta dan Kabupaten Lampung Barat sebanyak 789 peserta (Dinkes Provinsi Lampung, 2020).

Puskesmas Kenali merupakan salah satu puskesmas yang berada di Kabupaten Lampung Barat, puskesmas Kenali melayani, pemeriksaan umum maupun spesialis, dengan didukung peralatan yang sudah memadai untuk 
tindakan, selain melayani pemeriksaan umum, dan penyuluhan serta melaksanakan program posyandu, puskesmas juga melayani pemasangan alat kontrasepsi atau $\mathrm{KB}$, Strategi Puskesmas Kenali yang sudah di lakukan dalam meningkatkan cakupan pemasangan IUD pada Pasangan Usia subur dimulai dari pemasangan IUD gratis di Puskesmas, melakukan jemput bola (pelayanan yang mengambil ke wilayah pekon-pekon), pemberian penyuluhan di Posyandu, Sosialisasi KB pasca Salin.

Berdasarkan data yang telah diperoleh dapat diinterprestasikan bahwa penggunaan kontrasepsi IUD masih rendah dibandingkan kontrasepsi lain yang termasuk dalam non-IUD. Rendahnya penggunaan kontrasepsi IUD disebabkan oleh berbagai faktor, salah satunya adalah tingkat pengetahuan. Kurangnya pengetahuan tentang alat kontrasepsi IUD yang meliputi pengertian, keuntungan, efek samping, waktu yang tepat untuk pemasangan membuat akseptor KB takut untuk menggunakan IUD. Penurunan penggunaan kontrasepsi IUD pada akseptor KB dan banyaknya faktor yang mempengaruhi keputusan dalam penggunaan kontrasepsi sehingga terkadang dalam mengambil keputusan tersebut tidak sesuai dengan kondisi akseptor. Maka tujuan penelitian ini adakah untuk mengetahui faktor-faktor yang mempengaruhi pemilihan alat kontrasepsi non hormonal (IUD) dengan faktor yang di teliti adalah pengetahuan, sikap, social ekonomi, saran dan prasarana, dukungan suami, petugas kesehatan, kebutuhan penillaian pribadi serta kebutuhan penilaian klinik di wilayah kerja UPT Puskesmas Kenali
Kabupaten Lampung Barat tahun 2020.

\section{METODE}

Penelitian ini di lakukan dengan pendekatan kuantitatif. Pengumpulan data dilakukan dengan menggunakan kuisioner untuk variabel pengetahuan, sikap, social ekonomi, saran dan prasarana, dukungan suami, petugas kesehatan, kebutuhan penillaian pribadi serta kebutuhan penilaian klinik. Penelitian ini menggunakan desain Cross-Sectional. Populasi dalam penelitian ini adalah seluruh peserta KB aktif yang ada di wilayah kerja Puskesmas Kenali. Penelitian dilakukan di wilayah kerja UPT Puskesmas Kenali Kabupaten Lampung Barat. Penelitian telah dilaksanakan bulan April-Juli 2020. Pengambilan data dengan kuesioner. Tujuan dari penelitian ini adalah untuk mengetahui aktor yang mempengaruhi pemilihan alat kontrasepsi non hormonal (IUD) di wilayah kerja UPT Puskesmas Kenali Kabupaten Lampung Barat tahun 2020. Populasi dalam penelitian ini sebanyak 3666 peserta KB aktif hormonal dan non hormonal, sampel penelitian sebanyak 238 peserta KB aktif Pengambilan sampel dengan cara accidental Sampling. Analisa data yang di pakai adalah analisa univariat, bivariate dengan menggunakan uji Chi-square dan analisa multivariate dengan menggunakan uji regresi logistik.

\section{HASIL}

Penelitian ini dilakukan di wilayah kerja UPT Puskesmas Kenali Kabupaten Lampung Barat pada bulan April-Juni 2020. Penelitian ini untuk mengetahui faktor yang mempengaruhi pemilihan alat kontrasepsi non hormonal (IUD) di wilayah kerja UPT Puskesmas Kenali 
Kabupaten Lampung Barat tahun 2020. Jumlah sampel penelitian sebanyak 238 peserta KB aktif, pengambilan sampel dengan cara accidental sampling. Dari penelitian yang dilakukan dengan pengambilan data dan pengisian informed consent pada seluruh peserta KB aktif yang ada di wilayah kerja Puskesmas Kenali, diperoleh hasil sebagai berikut:

Tabel 1. Distribusi Karakteristik Responden

\begin{tabular}{llcc}
\hline \multicolumn{1}{c}{ Variabel } & \multicolumn{1}{c}{ Kategori } & $\mathbf{n}$ & $\mathbf{\%}$ \\
\hline Usia & $<20$ tahun & 21 & 8,8 \\
& $>35$ tahun & 217 & 91,2 \\
\hline Jumlah anak & 1 & 51 & 21,3 \\
& $>4$ & 187 & 78,7 \\
\hline Pendidikan & Rendah SD-SMP) & 34 & 14,2 \\
& Tinggi (SMA\& sarjana) & 168 & 85,8 \\
\hline Pekerjaan & IRT & 114 & 47,8 \\
& Bekerja & 125 & 52,2 \\
\hline
\end{tabular}

Tabel 2. Distribusi Frekuensi Responden

\begin{tabular}{llcc}
\hline \multicolumn{1}{c}{ Variabel } & Kategori & n & \% \\
\hline Kontrasepsi & hormonal & 190 & 79,8 \\
Kontrasepsi & (IUD) & 48 & 20,2 \\
Hormonal & Suntik & 88 & 46,4 \\
Pengetahuan & Pil & 83 & 43,6 \\
& Implan & 19 & 10 \\
Sikap & kurang baik & 111 & 46,6 \\
& baik & 127 & 53,4 \\
Status ekonomi & negatif & 121 & 50,8 \\
& positif & 117 & 49,2 \\
Ketersediaan alat & <UMK & 105 & 44,1 \\
& tidak & 133 & 55,9 \\
Dukungan suami & ada & 99 & 41,6 \\
& tidak & 139 & 58,4 \\
peran petugas & didukung & 135 & 56,7 \\
kesehatan & didukung & 103 & 43,3 \\
Penilaian pribadi & negatif & 77 & 32,4 \\
Penilaian klinis & positif & 161 & 67,6 \\
& tidak butuh & 180 & 75,6 \\
& butuh & 58 & 24,4 \\
& ada & 57 & 23,9 \\
\hline
\end{tabular}

Berdasarkan tabel 1 diketahui bahwa usia terbanyak adalah usia > 35 tahun yaitu sebanyak 217 orang $(91,2 \%)$, sebagian besar responden memiliki anak $>4$ yaitu sebanyak 187 orang $(78,7 \%)$. Sebagian besar responden memiliki pendidikan menengah sebanyak 168 (70,5\%). Sebagian besar responden memiliki pekerjaan IRT sebanyak 114 $(47,8 \%)$. Berdasarkan tabel 2 diketahui responden yang memilih kontrasepsi hormonal sebanyak 190 responden $(79,8 \%)$. Responden yang memilih kontrasepsi hormonal suntik sebanyak 88 responden $(46,4 \%)$. Responden yang berpengetahuan baik sebanyak 127 $(53,4 \%)$, Responden bersikap negatif sebanyak 121 (50,8\%). Responden dengan status ekonomi $\geq$ UMK sebanyak 133 (55,9\%). Distribusi frekuensi ketersedian alat, sebanyak 139 (58,4\%). Responden tidak mendapat dukungan suami sebanyak $135(56,7 \%)$ responden. 
Peran yang positif dari petugas kesehatan sebanyak $161(67,6 \%)$ responden. Responden mengatakan memiliki penilaian pribadi (tidak membutuhkan kontrasepsi IUD) dalam penggunaan kontrasepsi, sebanyak 180 (75,6\%). Responden yang tidak berdasarkan penilaian klinis dalam memilih kontrasepsi, yaitu sebanyak $181(76,1 \%)$.

Tabel 3. Faktor yang mempengaruhi pemilihan alat kontrasepsi non hormonal (IUD) di wilayah kerja UPT Puskesmas Kenali Kabupaten Lampung Barat tahun 2020

\begin{tabular}{|c|c|c|c|c|c|c|c|c|c|}
\hline \multirow[t]{3}{*}{ Variabel } & \multirow[t]{3}{*}{ Kategori } & \multicolumn{4}{|c|}{ Pemilihan kontrasepsi } & \multirow{3}{*}{\multicolumn{2}{|c|}{ n $\%$}} & \multirow{3}{*}{$\begin{array}{c}\text { P- } \\
\text { Value }\end{array}$} & \multirow[t]{3}{*}{$95 \%$ CI } \\
\hline & & \multicolumn{2}{|c|}{ Non IUD } & \multicolumn{2}{|c|}{ IUD } & & & & \\
\hline & & $\mathbf{n}$ & $\%$ & $\mathbf{n}$ & $\%$ & & & & \\
\hline \multirow[t]{2}{*}{ Pengetahuan } & $\begin{array}{l}\text { Kurang } \\
\text { baik }\end{array}$ & 96 & 86,5 & 15 & 13,5 & 111 & 100,0 & \multirow[t]{2}{*}{0,026} & \multirow{2}{*}{$\begin{array}{c}2.247 \\
(1.146-4.405)\end{array}$} \\
\hline & Baik & 94 & 74,0 & 33 & 26,0 & 127 & 100,0 & & \\
\hline \multirow[t]{2}{*}{ Sikap } & Negatif & 106 & 87,6 & 15 & 12,4 & 121 & 100,0 & \multirow{2}{*}{0,004} & \multirow{2}{*}{$\begin{array}{c}2.776 \\
(1.415-5.448)\end{array}$} \\
\hline & Positif & 84 & 71,8 & 33 & 28,2 & 117 & 100,0 & & \\
\hline \multirow{2}{*}{$\begin{array}{l}\text { Status } \\
\text { Ekonomi }\end{array}$} & Rendah & 92 & 87,6 & 13 & 12,4 & 105 & 100,0 & \multirow{2}{*}{0,013} & \multirow{2}{*}{$\begin{array}{c}2.527 \\
(1.259-5,076)\end{array}$} \\
\hline & Tinggi & 98 & 73,7 & 35 & 26,3 & 133 & 100,0 & & \\
\hline \multirow{2}{*}{$\begin{array}{l}\text { Ketersediaan } \\
\text { alat } \\
\text { kontrasepsi }\end{array}$} & $\begin{array}{l}\text { Tidak } \\
\text { ada }\end{array}$ & 78 & 78,8 & 21 & 21,2 & 99 & 100,0 & \multirow{2}{*}{0,861} & \\
\hline & Ada & 112 & 80,6 & 27 & 19,4 & 139 & 100,0 & & \\
\hline \multirow[t]{2}{*}{$\begin{array}{l}\text { Dukungan } \\
\text { suami }\end{array}$} & $\begin{array}{l}\text { Tidak } \\
\text { didukung }\end{array}$ & 125 & 92,6 & 10 & 7,4 & 135 & 100,0 & \multirow{2}{*}{0,000} & \multirow{2}{*}{$\begin{array}{c}7,308 \\
(3,423-15,600)\end{array}$} \\
\hline & Didukung & 65 & 63,1 & 38 & 36,9 & 103 & 100,0 & & \\
\hline \multirow{2}{*}{$\begin{array}{l}\text { Peran } \\
\text { petugas }\end{array}$} & Negatif & 62 & 80,5 & 15 & 19,5 & 77 & 100,0 & \multirow[b]{2}{*}{0,992} & \\
\hline & Positif & 128 & 79,5 & 33 & 20,5 & 161 & 100,0 & & \\
\hline \multirow[t]{2}{*}{$\begin{array}{l}\text { Penilaian } \\
\text { pribadi }\end{array}$} & $\begin{array}{l}\text { Tidak } \\
\text { butuh }\end{array}$ & 159 & 88,3 & 21 & 11,7 & 180 & 100,0 & \multirow[t]{2}{*}{0,000} & \multirow[t]{2}{*}{$\begin{array}{c}6,594 \\
(3,314-13,131)\end{array}$} \\
\hline & $\mathrm{Ya}$ & 31 & 53,4 & 27 & 46,6 & 58 & 100,0 & & \\
\hline \multirow{2}{*}{$\begin{array}{l}\text { Penilaian } \\
\text { klinis }\end{array}$} & $\mathrm{Ya}$ & 43 & 75,4 & 14 & 24,6 & 57 & 100,0 & \multirow[b]{2}{*}{0,448} & \\
\hline & Tidak & 147 & 81,2 & 34 & 18,8 & 181 & 100,0 & & \\
\hline
\end{tabular}

Tabel 4 Analisis Multivariat

\begin{tabular}{lrrrr}
\hline \multicolumn{1}{c}{ Variabel } & $\boldsymbol{p}$-value & OR & \multicolumn{2}{c}{ 95\% CI } \\
\hline Sikap &, 040 & 2,259 & 1,03 & 4,91 \\
\hline Penilaian_priibadi &, 000 & 8,178 & 3,62 & 18,47 \\
\hline Dukungan_suami &, 000 & 8,635 & 3,67 & 20,30 \\
\hline
\end{tabular}

Berdasarkan tabel 4 didapatkan bahwa model multivariat tahap III ternyata tidak ada variabel yang memiliki nilai $p$-value $>0,05$, didapati variabel dengan nilai OR tertinggi adalah dukungan suami yaitu sebesar 8,635 sehingga dapat disimpulkan bahwa dukungan suami merupakan faktor dominan dengan pemilihan kontrasepsi IUD.

\section{PEMBAHASAN}

Hasil uji statistik diperoleh $p$ value $=0,026$ yang berarti $<a$, maka dapat disimpulkan bahwa ada hubungan yang bermakna antara pengetahuan dengan pemilihan alat kontrasepsi pada wanita usia subur di Wilayah Kerja Puskesmas Kenali Kabupaten Lampung Barat tahun 2020 . Dengan nilai OR 2.247 berarti responden yang berpengetahuan kurang baik memiliki resiko sebesar 2,2 kali untuk memilih kontrasepsi non IUD dibandingkan dengan berpengetahuan baik. Pengetahuan merupakan hasil dari tahu dan ini setelah orang melakukan penginderaan terhadap obyek tertentu. Penginderaan terjadi melalui panca indera manusia, yakni indera penglihatan, pendengaran, 
penciuman, rasa dan raba. Sebagaian besar pengetahuan manusia diperoleh melalui mata dan telinga. Dari beberapa pengertian pengetahuan di atas dapat disimpulkan bahwa pengetahuan merupakan segala sesuatu yang diketahui yang diperoleh dari persentuhan panca indera terhadap objek tertentu (Notoatmodjo, 2014). Penelitian ini sejalan dengan penelitian (Veronica, Safitri, \& Rohani, 2019)Hasil penelitian adalah sebagian besar responden berpengetahuan kurang sebanyak 177 orang $(88,5 \%)$ dan tidak menggunakan KB IUD. didapatkan nilai signifikan (2-tailed) 0,000. Dengan demikian $\mathrm{HO}$ ditolak dan $\mathrm{H} 1$ diterima. Menurut pendapat peneliti pengetahuan merupakan hasil dari cari tahu sebelum seseorang mengadopsi perilaku atau norma baru, mereka terlebih dahulu mencari tahu apa arti dan manfaat perilaku tersebut bagi dirinya dan keluarganya. Seseorang yang mempunyai pengetahuan yang baik tentang kontrasepsi maka akan lebih memilih memakai kontrasepsi sedangkan seseorang yang mempunyai pengetahuan kurang baik maka akan kecil kemungkinan untuk memilih memakai kontrasepsi. Kontrasepsi tidak selalu membuat responden memilih kontrasepsi tersebut karena masih banyak faktor yang terkait yang akhirnya mempengaruhi keputusan ibu / wanita usia subur dalam memilih kontrasepsi seperti persepsi terhadap kesehatannya, seperti melihat efek samping yang ada pada alat kontasepsi tersebut, kemudian dukungan suami dalam pemilihan kontrasepsi.

Hasil uji statistik diperoleh $p$ value $=0,004$ yang berarti $\mathrm{p}<\mathrm{a}=$ 0,05 (Ho ditolak dan Ha diterima), maka dapat disimpulkan bahwa ada hubungan yang bermakna antara sikap dengan pemilihan alat kontrasepsi pada wanita usia subur di Wilayah Kerja Puskesmas Kenali Kabupaten Lampung Barat tahun 2020 . Dengan nilai OR 2.776 berarti responden yang memiliki sikap negatif terhadap pemilihan kontrasepsi memiliki resiko 2,3 kali lebih besar untuk memilih kontrasepsi non IUD dibandingkan dengan yang bersikap positif. Sikap sebagai suatu pola perilaku, tendensi atau kesiapan antisipatif, predisposisi untuk menyesuaikan diri dalam situasi sosial, atau secara sederhana, sikap adalah respon terhadap stimuli sosial yang telah terkondisikan. sikap adalah pandangan atau perasaan yang disertai kecenderungan untuk bertindak terhadap obyek tertentu. (Azwar, 2016). Hasil penelitian ini sesuai dengan penelitian (Ismun \& Sari, 2019) Hasil penelitian ini adalah sikap WUS ( $p$-value = 0,0003 ) dengan perilaku penggunaan AKDR pada WUS di wilayah kerja Puskesmas Payung Sekaki Kota Pekanbaru. Pengetahuan WUS yang baik terhadap AKDR diharapkan akan menghasilkan sikap WUS terhadap AKDR yang baik pula. Simpulan penelitian ini adalah sikap WUS dengan perilaku penggunaan AKDR pada WUS di wilayah kerja Puskesmas Payung Sekaki Kota Pekanbaru. Menurut pendapat peneliti, pada responden dengan sikap positif namun masih memilih kontrasepsi non IUD, karena banyak faktor yang mempengaruhi penggunaan kontrasepsi, seperti pengaruh dari informasi kawan, pengalaman kawan atau saran dari suami sehingga walaupun responden bersikap positif, namun tetap memilih memilih kontrasepsi non IUD. Dalam penggunaan AKDR, 
walaupun seseorang memiliki sikap yang cukup baik, namun perilaku yang muncul dapat menggunakan atau tidak menggunakan AKDR, karena dipengaruhi oleh determinan perilaku itu sendiri. Perilaku WUS dalam penggunaan AKDR dipengaruhi oleh faktor pemudah (pengetahuan, sikap, kepercayaan, keyakinan, tradisi, ekonomi, jumlah anak), faktor pemungkin (sarana dan prasarana fasilitas kesehatan, pelayanan KB), dan faktor penguat (perilaku tenaga kesehatan dan partisipasi suami) terhadap penggunaan AKDR.

Hasil uji statistik diperoleh $p$ value $=0,005$ yang berarti $\mathrm{p}<\mathrm{a}=$ 0,05 (Ho ditolak dan Ha diterima), maka dapat disimpulkan bahwa ada hubungan yang bermakna antara status ekonomi dengan pemilihan alat kontrasepsi pada wanita usia subur di Wilayah Kerja Puskesmas Kenali Kabupaten Lampung Barat tahun 2020 . Dengan nilai OR 2.527 berarti responden dengan status ekonomi rendah memiliki resiko sebesar 2,5 kali lebih besar untuk memilih kontrasepsi non IUD dibandingkan dengan status ekonomi tinggi Tinggi rendahnya status sosial ekonomi masyarakat mempengaruhi pemilihan jenis kontrasepsi karena dari tingkat ekonomi masyarakat berkaitan erat dengan kemampuan untuk membeli alat kontrasepsi yang akan digunakan misalnya keluarga yang berpenghasilan cukup akan lebih mampu mengikuti program KB dari pada keluarga yang tidak mampu, karena bagi keluarga yang kurang mampu KB bukanlah merupakan kebutuhan pokok (Lontaan, Kusmiyati, \& Dompas, 2014). Dalam lingkungan masyarakat kita melihat bahwa ada pembeda-bedaan yang berlaku dan diterima secara luas oleh masyarakat. Di sekitar kita ada orang yang menempati jabatan tinggi seperti gubernur dan wali kota dan jabatan rendah seperti camat dan lurah. Perbedaan ras, suku, agama, pendidikan, jenis kelamin, dan lain sebagainya juga membedakan manusia yang satu dengan yang lain (Notoatmodjo, 2012). Hasil Penelitian menyebutkan sebanyak 184 responden $(87,6 \%)$ menunjukkan kecenderungan minat untuk tetap memanfaatkan pelayanan kesehatan setelah kenaikan tarif. Dari data sekunder terlihat bahwa pengaruh kenaikan tarif terhadap koefisien elastisitas harga dari pemanfaatan pelayanan kesehatan rawat jalan bersifat inelastis $(E h<1)$, sehingga kenaikan tarif tersebut tidak berpengaruh pada tingkat pemanfaatan pelayanan kesehatan. Hasil analisis regresi dan korelasi menunjukkan bahwa keikutsertaan dalam asuransi kesehatan, kemauan membayar dan kemampuan membayar mempunyai pengaruh dan hubungan yang bermakna $(p<0,05)$ terhadap pemanfaatan pelayanan kesehatan setelah kenaikan tarif(Prasetya, 2015). Menurut pendapat peneliti pada status ekonomi rendah dan memilih kontrasepsi non IUD, sehubungan untuk memilih kontrasepsi non IUD memmerlukan dana lebih banyak dibandingkan dengan kontrasepsi non IUD sehingga hal ini pada akhirnya akan menyebabkan sesorang mengabaikan kesehatan dirinya. Angka akseptor KB dapat naikkan secara tidak langsung dengan memperbaiki status sosial ekonomi yang mempunyai efek terhadap salah satu dari seluruh faktor langsung yaitu perilaku kesehatan dan perilaku reproduksi, status kesehatan dan keterjangkauan pelayanan kesehatan. 
Hasil uji statistik diperoleh $p$ value $=0,000$ yang berarti $<a$, maka dapat disimpulkan bahwa ada hubungan yang bermakna antara dukungan suami dengan pemilihan alat kontrasepsi pada wanita usia subur di Wilayah Kerja Puskesmas Kenali Kabupaten Lampung Barat tahun 2020. Dengan nilai OR 7,308 berarti responden yang tidak didukung suami memiliki risiko sebesar 7,3 kali lebih besar untuk memilih kontrasepsi non IUD dibandingkan dengan yang di dukung suami. Motivasi berasal dari kata motif, yaitu suatu dorongan didalam diri seseorang yang menyebutkan orang tersebut melakukan kegiatan tertentu guna mencapai suatu tujuan. (Notoatmodjo, 2012) Jadi motivasi diartikan sebagai dorongan untuk bertindak untuk mencapai suatu tujuan tertentu. Pada umumnya, individu bersikap konformis atau searah dengan sikap orang orang yang dianggapnya penting. Kecenderungan ini antara lain dimotivasi oleh keinginan untuk berafiliasi dan keinginan untuk menghindari konflik dengan orang yang dianggap penting tersebut. Pada penelitian ini orang yang dimaksud adalah suami. Penelitian (Yanti, 2019) Hasil penelitian menunjukan bahwa Ada hubungan dukungan suami $((p=0,004<a=$ 0.05), $\quad(\mathrm{OR}=4,575)) \quad$ dengan penggunaan kontrasepsi MKJP sedangkan sikap tidak ada hubungan dengan penggunaan kontrasepsi MKJP $((p=0,0286<a=0.05)$, $(\mathrm{OR}=0,555))$ di Kecamatan Pesisir Selatan Kabupaten Pesisir Barat. (Epi Dusra, 2018). Menurut peneliti, dukungan suami berperan dalam pengambilan keputusan memilih kontrasepsi, karena ada suami yang tidak mendukung disebabkan ketidak tahuan suami akan manfaat dari kontrasepsi, sehingga diharapkan peran petugas kesehatan dalam menyikapi persoalan ini, dimana jika saat penyuluhan diharapkan suami ikut serta dalam penyuluhan tersebut, atau jika saat konseling tentang masalah kontrasepsi, suami harus turut serta ikut mendengarkan.

Hasil uji statistik diperoleh $p$ value $=0,000$ yang berarti $<a$, maka dapat disimpulkan bahwa ada hubungan yang bermakna antara penilaian pribadi dengan pemilihan alat kontrasepsi pada wanita usia subur di Wilayah Kerja Puskesmas Kenali Kabupaten Lampung Barat tahun 2020 . dengan nilai OR sebesar 6,594 artinya responden yang tidak butuh alat kontrasepsi IUD berdasarkan penilaian pribadi memiliki risiko sebesar 6,5 kali lebih besar akan menggunakan kontrasepsi non IUD jika dibandingkan dengan responden yang butuh kontrasepsi IUD berdasarkan penilaian pribadi. Konsep need merangkum beberapa penilaian efektifitas, potensi untuk mempertimbangkan berbagai cara untuk memenuhi need (dengan segala akibat yang ditimbulkannya) dan pengakuan akan adanya keterbatasan sumber daya serta dapat juga merupakan bentuk dasar bagi alokasi sumber daya. Pada umumnya akan lebih baik untuk memasukkan sekaligus need ketika melakukan pengujian beroperasinya suatu pelayanan kesehatan tertentu. Mengingat need dapat memberikan dasar yang cukup bagi pengambilan keputusan yang tepat(Priyoto, 2014).

Hasil uji statistik diperoleh $p$ value $=0,861$ yang berarti $>a$, maka dapat disimpulkan bahwa tidak ada hubungan yang bermakna antara ketersediaan alat kontrasepsi dengan pemilihan alat kontrasepsi 
pada wanita usia subur di Wilayah Kerja Puskesmas Kenali Kabupaten Lampung Barat tahun 2020. Menurut Anderson ketersediaan sarana dan prasarana, jarak merupakan penghalang yang meningkatkan kecenderungan penundaan upaya seseorang atau masyarakat dalam mencari pelayanan kesehatan (Priyoto, 2014). Masyarakat diharapkan dapat memanfaatkan pelayanan kesehatan (dalam hal ini Puskesmas) untuk keluarganya Penelitian menyebutkan ada hubungan yang signifikan antara jarak, biaya dengan pemanfaatan pelayanan pengobatan di Puskesmas (Irawan \& Ainy, 2018), tetapi berbeda dengan penelitian yang menyebutkan tidak ada hubumgan signifikan $(p>0,05)$ antara jarak dengan pemanfaatan Pustu (Tika \& Widya, 2019). Hasil penelitian menunjukkan bahwa hampir seluruh responden menjawab terjangkau dalam menempuh perjalanan ke sarana pelayanan kesehatan terdekat yaitu sebanyak 206 orang $(98,6 \%)$, sedangkan yang tidak terjangkau yaitu sebanyak 3 orang $(1,4 \%)$ (Prasetyo, 2018). Pemilihan fasilitas kesehatan dalam hal pemasangan alat kontrasepsi jangka panjang ini tidak terlepas dari kepercayaan masyarakat, apabila masyarakat memilih memasang kontrasepsi di RS yang besar, maka masyarakat beranggapan bahwa fasilitas lengkap dan terjamin, tenaga kesehatan memiliki kualifikasi yang baik, serta kelengkapan alat bantu medis yang memadai. Perbaikan dan penyampaian pelayanan serta akses yang mudah dijangkau dapat meningkatkan proporsi pemakaian kontrasepsi. Menurut peneliti ketersediaan alat saat dalam pelayanan kontrasepsi walaupun dalam hasil penelitian tidak berhubungan dengan penggunaan kontrasepsi, namun petugas kesehatan harus terus melakukan pengecekan alat / obat kontrasepsi sehingga jika suatu saat terdapat akseptor yang menginginkan penggunaan alat kongtrasepsi IUD dapat langsung digunakan, sehingga akseptor tidak beralih lagi ke kontrasepsi Non IUD.

Hasil uji statistik diperoleh $p$ value $=0,992$ yang berarti $>a$, maka dapat disimpulkan bahwa tidak ada hubungan yang bermakna antara peran petugas kesehatan dengan pemilihan alat kontrasepsi pada wanita usia subur di Wilayah Kerja Puskesmas Kenali Kabupaten Lampung Barat tahun 2020. Sejalan dengan penelitian yang dilakukan oleh diperoleh hasil nilai $(p=0,062)$. Berarti ada pengaruh yang signifikan antara peran petugas kesehatan dengan pemilihan metode kontrasepsi pada pasangan usia subut di kelurahan losung kecamatan padangsidimpuan selatan (Epi Dusra, 2018). Penelitian Hasil penelitian diperoleh nilai signifikasi peran petugas kesehatan $(p=0,489)$. Hasil tersebut dapat disimpulkan bahwa peran petugas kesehatan tidak terdapat hubungan yang signifikan terhadap pemilihan metode kontrasepsi(Epi Dusra, 2018),

Peneliti berasumsi Tenaga kesehatan memegang peranan penting dalam memberikan informasi tentang metode KB calon akseptor yang dalam hal ini khusus ibu hamil, bersalin dan nifas. Pemberian informasi ini dilakukan melalui konseling dengan menggunakan Alat Bantu Pengambilan Keputusan berKB. Sebagian besar responden mendapatkan dukungan dari petugas kesehatan, dukungan tersebut salah satunya seperti petugas kesehatan menjelaskan terlebih dahulu tentang 
alat kontrasepsi yang akan dipilih oleh responden dan efek sampingnya dan memberikan kebebasan kepada responden dalam menggunakan alat kontrasepsi yang sesuai dengan kondisinya. Sebagai sarana komunikasi, berbagai bentuk media massa seperti $\mathrm{TV}$, radio, internet, mempunyai pengaruh besar terhadap pembentukan opini dan kepercayaan orang.

Hasil uji statistik diperoleh $p$ value $=0,448$ yang berarti $\mathrm{p}>\mathrm{a}=$ 0,05 (Ho diterima dan Ha ditolak), maka dapat disimpulkan bahwa tidak ada hubungan yang bermakna antara penilaian klinis dengan pemilihan alat kontrasepsi pada wanita usia subur di Wilayah Kerja Puskesmas Kenali Kabupaten Lampung Barat tahun 2020. Kebutuhan seseorang terhadap pelayanan kesehatan adalah sesuatu yang subjektif, karena merupakan wujud dari masalah-masalah kesehatan yang ada di masyarakat yang tercermin dari gambaran pola penyakit. Dengan demikian untuk menentukan perkembangan kebutuhan terhadap pelayanan kesehatan dapat mengacu pada perkembangan pola penyakit yang ada pada individu tersebut. Menurut peneliti, diharapkan kesadaran dari akseptor untuk dapat memeriksakan kondisi yang dialami, dalam penggunaan kontrasepsi biasanya dilakukan pengecekan kesehatan terutama tekanan darah, jika sudah terdeteksi adanya kelainan misalnya tekanan darah tinggi, diharapkan peran petugas kesehatan untuk dapat memberikan konseling kepada ibu sehingga ibu dapat memilih kontrasepsi jenis lain yang tidak berpengaruh pada kondisi kesehatannya

\section{KESIMPULAN}

Ada hubungan tingkat pengetahuan, sikap, status ekonomi, dukungan suami, penilaian individu dengan pemilihan alat kontrasepsi alat kontrasepsi non hormonal (IUD). Faktor dukungan suami merupakan faktor yang paling dominan pada pemilihan alat kontrasepsi non hormonal (IUD).

\section{SARAN}

Membuka kelas bagi WUS, yang merupakan salah satu pendidikan non formal yang didapat dari petugas kesehatan seperti kegiatan penyuluhan kontrasepsi, konseling penggunaan kontrasepsi dan pelayanan kontrasepsi langsung, yang dilakukan rutin setiap bulan.

Meningkatkan dukungan suami, dengan memberikan edukasi dan konseling kepada suami terkait dengan kontrasepsi IUD, bisa dengan penyuluhan yang diadakan di balai desa, memberikan leaflet kepada suami yang berisikan materi tentang manfaat kontrasepsi IUD.

Lebih meningkatkan keterampilan kepada petugas dilapangan terutama bidan desa tentang teknik penyuluhan, serta memberikan fasilitas untuk penyuluhan yang lebih memadai hingga akseptor lebih tertarik untuk menggunakan IUD.

\section{DAFTAR PUSTAKA}

Azwar. (2016). Sikap dan pengukuran Sikap (1st ed.). Rineka Cipta: Jakarta.

Bella Putri Sinta Prastika. (2019). Hubungan Dukungan Suami Dan Gaya Hidup Dengan Kualitas Hidup Akseptor $\mathrm{Kb}$ Iud $\mathrm{Di}$ Wilayah Puskesmas Mulyorejo Surabaya. Ayan, 8(2), 2019. https://doi.org/10.22201/fq.187 08404e.2004.3.66178

Dinkes Provinsi Lampung. (2020). 
Profil Kesehatan Lampung Tahun 2019. (62), 4437-4439.

Epi Dusra. (2018). Analisis Hubungan Peran Petugas Kesehatan Dengan Pemilihan Metode Kontrasepsi Jangka Panjang Pada Akseptor Di Wilayah Kerja Puskesmas Hitu Kabupaten Maluku Tengah Tahun 2017. 9, 210-214.

Irawan, B., \& Ainy, A. (2018). Analisis Faktor-Faktor Yang Berhubungan Dengan Pemanfaatan Pelayanan Kesehatan Pada Peserta Jaminan Kesehatan Nasional Di Wilayah Kerja Puskesmas Payakabung, Kabupaten Ogan Ilir. Jurnal I/mu Kesehatan Masyarakat, 9(3), 189-197.

https://doi.org/10.26553/jikm.v 9i3.311

Ismun, N. D., \& Sari, T. W. (2019). Hubungan Pengetahuan Dan Sikap Wanita Usia Subur (Wus) Dengan Perilaku Penggunaan Alat Kontrasepsi Dalam Rahim (Akdr) Di Wilayah Kerja Puskesmas Payung Sekaki Kota Pekanbaru. Journal of Midwifery Science (JOMIS), 3(1), 25-31. Retrieved from http://jurnal.univrab.ac.id/index .php/jomis/article/view/649/458

Lontaan, A., Kusmiyati, K., \& Dompas, R. (2014). Faktor Faktor Yang Berhubungan Dengan Pemilihan Kontrasepsi Pasangan Usia Subur Di Puskesmas Damau Kabupaten Talaud. Jurnal IImiah Bidan, 2(1), 91154.
Mulyani, N. S., \& Rinawati, M. (2013). Keluarga berencana dan alat kontrasepsi.

Notoatmodjo. (2012). Promosi Kesehatan dan Perilaku Kesehatan. Jakarta: PT. Rineka Cipta.

Notoatmodjo. (2014). Ilmu dan seni kesehatan masyarakat.

Prasetya. (2015). Mutu pelayanan dan tarif pelayanan terhadap minat pemanfaatan ulang jasa rawat inap di rumah sakit mardi mulya trenggalek. 1-12.

Prasetyo, K. Y. (2018). Peran Posyandu Lansia dalam Meningkatkan Kesejahteraan Lansia di Kelurahan Sekaran Kecamatan Gunungpati Kiki. $3(6), 9-15$.

Priyoto. (2014). Teori Sikap dan Perilaku dalam Kesehatan. Yogyakarta: Nuha Medika.

Tika, M., \& Widya, C. (2019). Higeia Journal of Public Health. Higeia Journal of Public Health Research and Development, 1(3), 625-634.

Veronica, S. Y., Safitri, R., \& Rohani, S. (2019). Faktor - Faktor Yang Berhubungan Dengan Pemakaian KB IUD Pada Wanita Usia Subur. Wellness and Healthy Magazine, 1(2), 223230.

Yanti, D. E. (2019). Faktor Yang Berhubungan Dengan Penggunaan Metode Kontrasepsi Jangka Panjang Pada Akseptor Kb Aktif Di Kecamatan Pesisir Selatan Kabupaten Pesisir Barat Dhiny. 8(2), 1-2. 